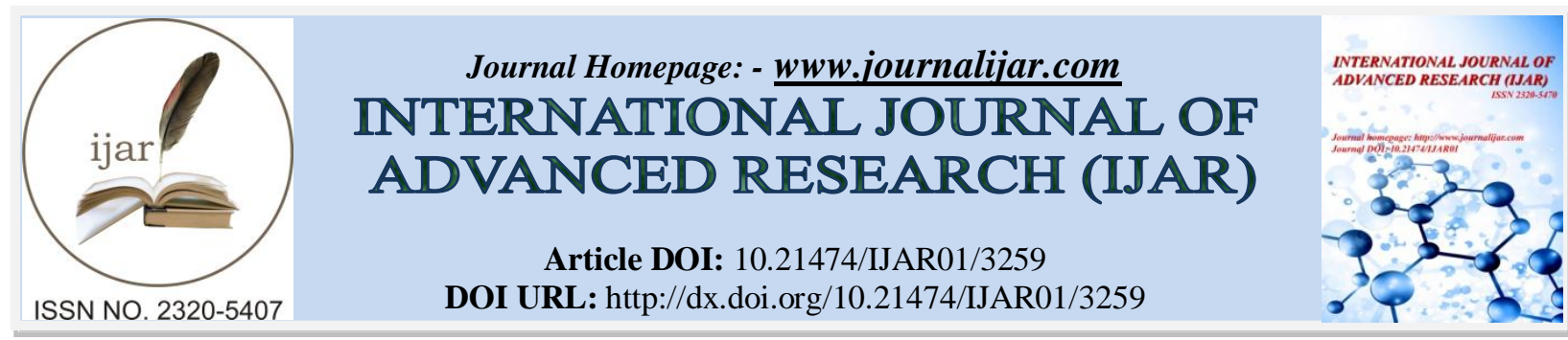

RESEARCH ARTICLE

\title{
A MULTI DIMENSIONAL EFFECT OF PANCHAKARMA IN THE MANAGEMENT OF TRAUMATIC PARAPLEGIA - A CASE STUDY.
}

Vd. Manikrao H Kulkarni.

Professor and H.O.D.Dept.of Panchakarma, S.S.V.P. Ayurvedic college and R.I., Hatta Dist..Hingoli MUHS Nashik Maharashtra, India.

\section{Manuscript Info}

Manuscript History

Received: 23 December 2016

Final Accepted: 20 January 2017

Published: February 2017

Key words:-

Traumatic Paraplegia, Kati basti, Patra

Pottali sweda, Panchatikta Ksheer basti.

\section{Abstract}

Aim of this study was to assess neurological improvement after administration of Panchakarma procedures in traumatic paraplegia. On the basis of MRI findings, patient was advised for the surgical intervention. As there is no satisfactory treatment available in biomedicine. The patient was treated with Kati basti, Sarvanga abhyanga nadi sweda Patra Pottali sweda, followed by Panchatikta Ksheera Basti (16 days) and shaman oushadhi upto 3 months Substantial improvement was reported after 3 months of Panchakarma and Shaman oushadhi in existing neurological deficits and in quality of life.

Copy Right, IJAR, 2017,. All rights reserved.

\section{Introduction:-}

Traumatic Paraplegia is an unanticipated catastrophe in an individual's life, passing a huge economic as well as social burden. The health care does not end with time but it involves multiple personnel and family members. In a developing country like India, where tertiary health care is not universally accessible and acceptable, the consequences of traumatic paraplegia and it's complications are unimaginable ${ }^{1}$. The prevalence of traumatic paraplegia in India is estimated 236 per million $^{2}$. It can be correlated with the Abhighatajanya Adharangavata ${ }^{3}$. Ayurvedic intervention in terms of Panchakarma and shaman oushadhi may impart significant recovery from traumatic paraplegia ${ }^{4}$. This case report is of a patient with Traumatic paraplegia with lesion at L4-L5, L5-S1 level with spinal canal stenosis, where we achieved substantial recovery with Panchakarama and shaman Yoga.

\section{Case Report:-}

A 53 years old patient came for consultation in Panchakarma OPD of S.S.V.P. Ayurvedic hospital, Maharashtra, India. He was admitted and thoroughly examined. It was revealed that he was unable to move his both lower limbs. He was fully conscious but he was not able to move his lower part of body. Patient had autonomic dysfunction and was neither able to feel nor control the urge for micturation and defecation.

The patient had a history of trauma due to accidental injury happened in the afternoon when he was going to sell his milk 6 months back. After the accident, patient was unconscious for $1 \frac{1}{2} \mathrm{Hrs}$. and regained consciousness on the way to hospital. He was admitted in I.C.U. for 8 days with administration of other supportive medication. There also patient had incontinence of urine and stool. Patient's MRI was done. This revealed multiple level prolapsed intravertebral discs with spinal canal stenosis L4-L5 and L5-S1 with disc buldge with ligamentum flavum hypertroply. 
The patient was not getting any response from the treatment and the patient was advised for surgical intervention by neurosurgeon. Recommended physiotherapy was continued for 3 months, but no improvement was seen in the clinical condition.

After that the patient came to our institute for the needful. He was diagnosed as Abighatajanya Adharangavata and was treated by the line of treatment of vata vyadhi ${ }^{5}$.

$\begin{array}{lll}\text { Diagnosis } & - & \text { Abhighatajanya Adharangavata. } \\ \text { Date of admission } & - & 17 / 02 / 2016 \\ \text { Date of discharge } & - & 28 / 04 / 2016\end{array}$

Principle of Treatment:-

Reduce the pain inflammation, improve the movement, promote blood circulation, increase muscle tone and relax the muscles and improvement in neurological deficits. .

Treatment Given:-

\begin{tabular}{|c|c|c|c|}
\hline Panchakarma Procedure & Materials & Dose/day & Duration. \\
\hline 1. Katibasti & Bala ashwagandha taila & 100 to $120 \mathrm{ml}$ & $\begin{array}{l}20 \text { to } 25 \mathrm{~min} \text {. for } 16 \\
\text { days }\end{array}$ \\
\hline 2. Sarvanga abhyanga & Bala taila & app 60 to $70 \mathrm{ml}$ & 20 min. for 16 days \\
\hline 3. Nadi swedana & Dashamoola kwatha & - & $\begin{array}{l}10 \text { to } 15 \text { min. for } 16 \\
\text { days }\end{array}$ \\
\hline 4.Patra Pottali sweda & $\begin{array}{l}\text { Eranda, Arka, Nirgundi, shigru } \\
\text { patra, Mustard and Fenugreek } \\
\text { powder +lemon juice }\end{array}$ & $\begin{array}{l}\text { App. } 400 \text { to } 500 \mathrm{gm} \\
\text { bolus }\end{array}$ & $\begin{array}{l}20 \text { to } 25 \mathrm{~min} \text { for } 16 \\
\text { days }\end{array}$ \\
\hline $\begin{array}{ll}\text { 2. Panchatikta } & \text { Ksheera } \\
\text { Basti } & \\
\end{array}$ & $\begin{array}{l}\text { Guduchi, Patola, Nimba, Kantakari, } \\
\text { Vasa + Panchatikta ghruta }\end{array}$ & 150 to $200 \mathrm{ml}$. & 15 days \\
\hline
\end{tabular}

Shaman Yoga:-

Rasaraja Ras(125 mg 1 ratti bd) + Ekangaveera rasa (125 mg 1 ratti bd) + Trayodashanga guggulu(3 gm / day) With Honey + ginger juice and Maharasnadi Kwatha. $\left(20 \mathrm{ml}\right.$ bd) was given for 3 months ${ }^{6,7}$.

\section{Asssesment Criteria:-}

1) Pricking pain

2) Stiffness

$\begin{array}{lll}1 & - & \text { Mild } \\ 2 & - & \text { Moderate } \\ 3 & - & \text { Severe }\end{array}$

Stiffness $\quad 0 \quad-\quad$ Absent

3 - 3 Severe

3) SLR Right $\quad 0 \quad-\quad$ No Movement

$\begin{array}{llll}\text { Left } & 0 & - & \text { No Movement. }\end{array}$

4) Ability to turn on bed $\quad$ - Absent

- Present

5) Ability to sit - $\quad$ Absent

With the support $\quad$ - $\quad$ Present

6) Ability to stand - Absent

- Present

7) Ability to walk - $\quad$ Absent

- $\quad$ Present 


\begin{tabular}{|l|l|l|}
\hline Signs and symptoms & BT & AT \\
\hline 1. Pricking Pain & 2 & 0 \\
\hline 2. Stiffness & 3 & 1 \\
\hline 3. SLR Right & 0 & $70^{0}$ \\
\hline SLR Left & 0 & $75^{0}$ \\
\hline 4. Ability to turn on bed & Absent & Present \\
\hline 5. Ability to sit with the support & Absent & Present \\
\hline 6. Ability to stand & Absent & Present \\
\hline 7. Ability to walk & Absent & Can walk more than 300 \\
& & mtrs in 20 min. \\
\hline 8. Muscles function grade & & 3 \\
Right hip & 0 & 3 \\
Left hip & 1 & 3 \\
Right knee & 1 & 3 \\
Left knee & 1 & 3 \\
Right ankle \& toe & 2 & 3 \\
Left ankle and toe & 2 & Absent \\
\hline 9. Sensory function & Present & Absent \\
tingling sensation & Present & Reduced \\
Numbness & Present & \\
\hline 10. Reflexes & & 1 \\
Right knee jerk & 2 & 1 \\
Left knee jerk & 2 & 1 \\
Right ankle jerk & 2 & 1 \\
Left ankle jerk & 1 & 1 \\
Superficial abdomen reflex & 1 & Present \\
Plantar reflex & Absent & Less spastic \\
\hline 11. Muscle tone right lower limb & Spastic & Less spastic \\
Muscle tone left lower limb & Spastic & Normal \\
\hline 12 Bowel activity & Incontinance & Normal \\
\hline 13 Bladder activity & Incontinance & \\
\hline
\end{tabular}

\section{Discussion:-}

As patient with traumatic Paraplegia, was correlated with abhigatajanya Adharangavata. The general line of treatment for vatavyadhi was adopted to treat this condition.

The mulasthana of this disease locates at Katipradesha. Kati basti was selected as a bahi parimarjana chikitsa with bala - ashwagandha taila to reduce inflammation, stiffness and to give nourishment to dhamani i.e. nerves. Sarvanga abhyanga and Nadi swedana was recommended which acts as passive exercise which brings relaxation in spinal musculeture of both lower limbs and reduced the spasticity.

As patient was admitted, in afternoon time, Patra pottali sweda was given to reduce pain, swelling and to improve the muscle tone.

Basti is the best treatment of vata. Pakwashaya is the main site of vata and basti mainly passes vata shamana property.

Mode of Action of Panchatikta Ksheera Basti:-

Considering the involvement of Asthi dhatu, majja dhatu, mamsa dhatu in Katipradesha and predominantly dosha as vyan vata Karmahani, Panchatikta Ksheera Basti was given.

Tikta rasa has vayu and akasha mahabhuta in dominance. Hence it has got affinity towards the body elements like Asthi dhatu.

Most of the ingredients of Panchatikta Ksheera Basti have tikta rasa, ushna virya madhura rasa and katu vipaka and shothagna property which helps to increase dhatwagni. So the nutrition of all dhatus will be increased. Ghrita is 
vatapittashaman, balya, agnivardhaka, madhura, soumya, sheet, vayusthapan so acts as a nourishment to pacify the vitiated vata.

Initially there was no retention of basti. Bowel evacuation was found only after Basti administration. The shaman yoga is helpful in vatika roga and showed balya and rasayana effect.

\section{Conclusion:-}

Sarvanga abhyanga, Nadi swedana, Katibasti, Patra pattali sweda, Dashamoola niruha and Pancha tikta Ksheera basti has given a miraculous results in this patient.

The patient was admitted for 2 months and 11 days and completely recovered from functional disability, pain and stiffness etc. The over all effect of all panchakarma procedures with shaman yoga showed a marked improvement in this patient. This approach may be useful for clinical practices and further studies also .

\section{References:-}

1. Hagen E.M., Rekand T, Gilhus N.E., Gronning M - Traumatic spinal and injuries - Incidence, mechanisms and course. TidssKr.Nar laegeforen 2012/132:831-7

2. Vale FL, Burns J, Jackson AB, Hadley MN, Combined medical and surgical treatment of after acute spinal cord injury. Results of a prospective pilot study to asses the merits of aggressive medical resuscitation and blood pressure management.

3. Yadavji Trikamji, editor, Ayurved Dipika, Sanskrit commentary, Charak Samhita, Chaukhamba Prakashan $2013-28^{\text {th }}$ Chap.

4. Vaidya Yadavji Trikamji, acharya, Sushruta Samhita with Dalhanacharya Nibandha Sangraha and Gayadasacharya Nyaychandrka Panjika Commentary edited by Krishnadas Academy, Varanasi, Edition reprint in 1998 -Uttartantra $55^{\text {th }}$ chapter / 4 P. No. 405

5. O.Mishra, S.Bhaisajya Ratnavali. Sidhiprada Hindi Commentary, Chapter 26 page 539, 548 Varanasi Chaukhamba Surbharati Prakashana 2007

6. Sharangadhar,Sharangadhar Samhita edited by Pt. Parashuram Shastri Vidyasagar $1987-3^{\text {rd }}$ edition. Chaukhamba Orientalia.Varanasi $2^{\text {nd }}$ Adhyaya Madhyam Khanda page 97.

7. Ayurveda Sar Sangraha, Baidyanath Ayurved Bhavan Pvt. Ltd., $8^{\text {th }}$ Edition -1972 Ras Rasayan Prakarana page 266-267 